\title{
The metabolism and motility of human spermatozoa in the presence of steroid hormones and synthetic progestagens
}

\author{
R. V. Hyne, R. N. Murdoch and B. Boettcher \\ Department of Biological Sciences, University of Newcastle, New South Wales, \\ 2308 Australia
}

\begin{abstract}
Summary. The metabolism and motility of human ejaculated spermatozoa incubated in vitro with steroids were studied. Progesterone and norethynodrel depressed the respiration, glycolytic metabolism and the motility of washed spermatozoa. Lynoestrenol did not affect the respiration or glycolysis of the spermatozoa, but did inhibit motility. Oestradiol did not cause any consistent alteration of the sperm metabolism, and did not affect the motility. Progesterone and norethynodrel appear to act on the plasma membrane of human spermatozoa to increase its permeability and hence to facilitate the loss of essential cofactors required for the glycolytic and oxidative processes.
\end{abstract}

\section{Introduction}

Some spermagglutinins, which induce head-to-head agglutination of human spermatozoa, represent a steroid attached to a carrier protein (Boettcher, 1974). This spermagglutinating activity can be induced in vitro by the addition of specific steroids such as progesterone to certain serum samples (Boettcher \& Kay, 1973) or in vivo in the serum of some women taking oral contraceptives for the first time (Boettcher, Hay, Kay, Baldo \& Roberts, 1970). Similar spermagglutinating activity can be produced in vivo in cervical mucus by intravenous injection of progesterone (Lindahl, IngelmanSundberg, Furuhjelm \& Nilsson, 1956). The naturally occurring spermagglutinating activity of cervical mucus from post-menopausal women can be decreased by the intravenous injection of oestradiol dipropionate (Lindahl et al., 1956).

Several reports indicate that steroids can affect the migration of human spermatozoa in vivo (Kesserü-Koos, 1971) and in vitro (Beck, Herschel, Hungerschöfer \& Schwinger, 1976; Kesserü, Camacho-Ortega, Laudahn \& Schöpflin, 1975) and sperm metabolism (Hicks, Pedron \& Rosado, 1972; Rosado, Hicks, Aznar \& Mercado, 1974). Steroids administered to women by intravenous injection have been shown to pass into the genital tract and appear in cervical mucus (Gallegos, González-Diddi, Merino \& Martínez-Manautou, 1970; Laumas, Murugesan \& Hingorani, 1971; Reed, Fotherby \& Steele, 1973; Reed, Fotherby, Peck \& Gordon, 1973) and follicular fluid (Braunsberg, Irvine \& James, 1967). It is therefore possible that steroids may exert a direct effect on spermatozoa as they pass through the female genital tract.

In preliminary experiments, an examination of the effect of a range of synthetic progestagens on human sperm migration and motility indicated that the progestagens lynoestrenol and norethynodrel had a strong inhibitory effect on spermatozoa. The present investigation was undertaken to evaluate the metabolism and motility of human spermatozoa in the presence of progesterone, oestradiol, lynoestrenol and norethynodrel.

\section{Materials and Methods}

\section{Semen}

Samples of semen from normal healthy donors were collected by masturbation into clean glass jars after a minimum of $48 \mathrm{~h}$ of sexual abstinence. The samples were allowed to liquefy in an incubator at $37^{\circ} \mathrm{C}$ before examination. Each semen sample was diluted with 5 volumes of diluent. An 
aliquot from each diluted sample was placed on a warm glass slide, covered with a coverslip and examined under a phase-contrast microscope $(\times 500)$. One hundred $(100)$ spermatozoa were examined at random and the number of motile spermatozoa was recorded: motility was rated from $0 \%$ (no cells motile) to $100 \%$ (all cells motile). Sperm concentration was determined by diluting the semen in 10 volumes of $3 \%(\mathrm{w} / \mathrm{v}) \mathrm{NaCl}$ solution and using a Petroff-Hausser bacterium counter. The cells were counted under a phase-contrast microscope $(\times 125)$ and the final concentrations varied between $0.9 \times 10^{8}$ and $2.6 \times 10^{8}$ spermatozoa/Warburg flask.

\section{Radioactive substrates}

Radioactive substrates were obtained from the Radiochemical Centre, Amersham, England, and were added to a Ca-free Krebs-Ringer-phosphate (KRP) diluent ( $\mathrm{pH} 7 \cdot 4$ ) (Deluca, 1972) to give the following concentrations/Warburg flask: $5 \mu \mathrm{mol}(500 \mathrm{nCi}) \mathrm{D}-\left[\mathrm{U}-{ }^{14} \mathrm{C}\right] \mathrm{glucose} ; 10 \mu \mathrm{mol}(500 \mathrm{nCi})$ $\left[1-{ }^{14} \mathrm{C}\right]$ acetate, sodium salt; $5 \mu \mathrm{mol}(50 \mathrm{nCi}) \alpha$-keto- $\left[5-{ }^{14} \mathrm{C}\right]$ glutaric acid, sodium salt; $5 \mu \mathrm{mol}(500$ nCi) $\left[1,4-{ }^{14} \mathrm{C}\right]$ succinic acid, and $5 \mu \mathrm{mol}(500 \mathrm{nCi}) \mathrm{L}-\left[\mathrm{U}-{ }^{14} \mathrm{C}\right] \mathrm{malic}$ acid. The succinate and malate solutions were adjusted to $\mathrm{pH} 7.4$ with $0.1 \mathrm{M}-\mathrm{NaOH}$ solution. The radiochemical purity of the citric acid cycle intermediates was established by descending paper chromatography with $n$-butanol: glacial acetic acid:water $(120: 30: 50$ by vol. $)$ as the solvent system. The radioactive succinic acid and malic acid were used as supplied, but it was necessary to purify the radioactive $\alpha$-ketoglutarate further by preparative paper chromatography with the above solvent system.

\section{Steroids}

Steroid hormones were dissolved in ethanol or in a benzene-ethanol $(9: 1 \mathrm{v} / \mathrm{v})$ solution and were added separately to Warburg flasks in $0.1 \mathrm{ml}$ solvent. Steroid-free solvent was added to control flasks. The solvent in each flask was evaporated under a stream of air before the addition of substrate and spermatozoa. Oestradiol (oestra-1,3,5(10)-triene-3,17 $\beta$-diol) and progesterone (pregn-4ene-3,20-dione) were from Sigma Chemical Co.; lynoestrenol (17 $\alpha$-ethynyl-oestr-4-en-17 $\beta$-ol) was from Organon (Australia) Pty Ltd, and norethynodrel (17 $\alpha$-ethynyl-17 $\beta$-hydroxyoestr-5(10)-en-3one) was from Searle Laboratories.

\section{Experiments}

Experiments were replicated 3 to 5 times with different pooled ejaculates from at least 5 donors for each replicate. After pooling the ejaculates, the spermatozoa were washed by diluting the semen with 3 volumes of the Ca-free KRP diluent, and centrifuging for $20 \mathrm{~min}$ at $400 \mathrm{~g}$. After aspiration of the supernatant, the spermatozoa were again washed in $5 \mathrm{ml}$ diluent and then suspended in $3 \mathrm{ml}$ diluent. The motility of the spermatozoa in the washed preparations varied from 35 to $70 \%$. Unless otherwise stated the washed sperm suspension $(0.5 \mathrm{ml})$ was incubated at $37^{\circ} \mathrm{C}$ for $3 \mathrm{~h}$ with $0.5 \mathrm{ml}$ of the appropriate substrate in $5 \mathrm{ml}$ Warburg flasks containing $0.1 \mathrm{ml} \mathrm{CO}_{2}$-free $20 \%(\mathrm{w} / \mathrm{v}) \mathrm{KOH}$ in the centre well. The rim of the centre well was coated with a thin layer of Apiezon grease to prevent migration of the reaction mixture into the $\mathrm{KOH}$. After allowing a 10-min period for temperature equilibration, the flasks were closed and oxygen utilization was measured manometrically with air as the gas phase and a shaking rate of 80 strokes $/ \mathrm{min}$. Substrate oxidation was determined from the assay of ${ }^{14} \mathrm{CO}_{2}$ trapped in the $\mathrm{KOH}$ of the centre well. The $\mathrm{KOH}$ was transferred to a scintillation vial with a Pasteur pipette and the centre wells of the flasks were twice washed with $0.35 \mathrm{ml}$ water. The combined solutions were counted by liquid scintillation techniques in $10 \mathrm{ml}$ scintillation fluid consisting of toluene: Brydet $(2: 1 \mathrm{v} / \mathrm{v})$ or toluene:Triton X-100 (2:1 v/v) (Patterson \& Greene, 1965) containing $0.4 \%(\mathrm{w} / \mathrm{v})$ 2,5-diphenyloxazole. Radioactivity was measured in a Packard Tri-Carb liquid scintillation spectrometer (Model 3385) and all counts were corrected for background. The efficiency of counting was measured by using the external standard ratio method and was found to be constant for each ${ }^{14} \mathrm{C}$-substrate. For experiments requiring anaerobic conditions, single side-arm Warburg flasks $(6 \mathrm{ml}$ capacity), containing $0.1 \mathrm{ml} 20 \%(\mathrm{w} / \mathrm{v}) \mathrm{KOH}$ in the centre well and $5 \mu \mathrm{mol}$ glucose in $0.5 \mathrm{ml}$ diluent in the side arm, were gassed for $10 \mathrm{~min}$ with nitrogen. The stop-cocks were then closed and the glucose solution tipped into the sperm suspension. 
In experiments with glucose as substrate, aliquots of the sperm suspension before incubation and the flask contents after incubation were deproteinized by the addition of $5 \%(\mathrm{w} / \mathrm{v}) \mathrm{ZnSO}_{4} .7 \mathrm{H}_{2} \mathrm{O}$ $(1 \mathrm{ml})$ and $0.3 \mathrm{~N}-\mathrm{Ba}(\mathrm{OH})_{2}(1 \mathrm{ml})$; glucose and lactate were then estimated in the filtrates by enzymic methods (Huggett \& Nixon, 1957; Barker \& Britton, 1957).

In experiments designed to assess the effects of steroids on the integrity of the sperm membrane, $5 \mathrm{ml} \mathrm{Warburg}$ flasks were prepared to contain $0.5 \mathrm{ml}$ sperm suspension, $0.5 \mathrm{ml}$ diluent and $320 \mathrm{nmol}$ steroid. Appropriate control flasks containing no added steroid were also employed. All fiasks contained $0 \cdot 1 \mathrm{ml} 20 \%(\mathrm{w} / \mathrm{v}) \mathrm{KOH}$ in the centre well and were incubated with air as the gas phase for $3 \mathrm{~h}$ at $37^{\circ} \mathrm{C}$. At the end of the incubation period, the reaction mixture in each flask was centrifuged at $1500 \mathrm{~g}$ for $15 \mathrm{~min}$ and the supernatant retained. An aliquot of the supernatant $(0.5 \mathrm{ml})$ was deproteinized with $5 \%(\mathrm{w} / \mathrm{v}) \mathrm{ZnSO}_{4} .7 \mathrm{H}_{2} \mathrm{O}(0.5 \mathrm{ml})$ and $0.3 \mathrm{~N}-\mathrm{Ba}(\mathrm{OH})_{2}(0.5 \mathrm{ml})$, diluted with distilled water $(1.5 \mathrm{ml})$, centrifuged at $1500 \mathrm{~g}$ for $10 \mathrm{~min}$, and measured for absorbance at $260 \mathrm{~nm}$. Allowances were made for absorbance at this wavelength due to the added steroids. The supernatant was also assayed for protein by the method of Lowry, Rosebrough, Farr \& Randall (1951).

\section{Statistical analysis}

The significance of the results was assessed by analysis of variance. The interaction mean square was used to calculate the standard errors (s.e.) of the differences between means as presented in the tables, and this was then used in $t$ tests.

\section{Results}

\section{Norethynodrel effects on the oxidative metabolism of glucose}

Various concentrations of norethynodrel were tested to assess the minimum concentration at which the steroid affected the oxidative metabolism of the spermatozoa (Table 1). A concentration of $320 \mathrm{nmol}$ norethynodrel/ml significantly depressed the oxygen consumption and the amount of glucose oxidized by the spermatozoa, but at $32 \mathrm{nmol} / \mathrm{ml}$ only the amount of glucose oxidized was affected. Preliminary experiments revealed that if acetate was used as substrate, norethynodrel at a concentration of $32 \mathrm{nmol} / \mathrm{ml}$ depressed both the amount of acetate oxidized and the oxygen consumed.

Table 1. The effect of various norethynodrel concentrations on the oxidative metabolism of $\mathrm{D}-\left[\mathrm{U}-{ }^{14} \mathrm{C}\right]$ glucose by washed human spermatozoa

\begin{tabular}{lcl}
\hline $\begin{array}{c}\text { Norethynodrel conc. } \\
(\mathrm{nmol} / \mathrm{ml})\end{array}$ & $\begin{array}{c}\text { Oxygen uptake } \\
(\mu \mathrm{l})\end{array}$ & $\begin{array}{c}\text { Glucose oxidized } \\
(\mu \mathrm{mol})\end{array}$ \\
\hline 0 (control) & $9 \cdot 1$ & 0.043 \\
0.32 & $9 \cdot 0$ & 0.041 \\
3.2 & $9 \cdot 3$ & 0.043 \\
32 & $9 \cdot 0$ & $0.038^{* *}$ \\
320 & $5 \cdot 7^{* * *}$ & $0.022^{* * *}$ \\
\hline s.e.m. & 0.18 & 0.001 \\
\hline
\end{tabular}

\footnotetext{
Values represent the means of 4 replicates and are calculated per $10^{8}$ spermatozoa per $3 \mathrm{~h}$.

Significantly different from control value, ${ }^{* *} P<0.01,{ }^{* * *} P<0.001$.
}

\section{Effect of steroids on the aerobic metabolism of glucose}

When low concentrations of steroids ( $32 \mathrm{pmol} / \mathrm{ml}$ ) were used (Table 2, Exp. 2A), oestradiol and lynoestrenol had no significant effect on the four metabolic indicators measured. Progesterone decreased the oxygen uptake of the spermatozoa, and enhanced the rate of lactate production but had no effect on the amount of glucose utilized or glucose oxidized. Norethynodrel decreased only the amount of oxygen consumed by the spermatozoa. 
The effects of high concentrations of steroids $(320 \mathrm{nmol} / \mathrm{ml})$ varied considerably (Table 2, Exp. 2B): oestradiol slightly depressed the oxygen uptake and increased the amount of lactate produced, lynoestrenol increased the amount of lactate produced, and progesterone and norethynodrel markedly depressed the oxidative and glycolytic metabolism of the spermatozoa.

Table 2. The effect of steroids $(32 \mathrm{pmol} / \mathrm{ml}$ in Exp. $2 \mathrm{~A}, 320 \mathrm{nmol} / \mathrm{ml}$ in Exp. 2B) on the aerobic metabolism of $\mathrm{D}-\left[\mathrm{U}-{ }^{14} \mathrm{C}\right] \mathrm{glucose}$ by washed human spermatozoa

\begin{tabular}{|c|c|c|c|c|c|}
\hline Exp. & Steroid & $\begin{array}{l}\text { Oxygen } \\
\text { uptake } \\
(\mu l)\end{array}$ & $\begin{array}{c}\text { Glucose } \\
\text { oxidized } \\
(\mu \mathrm{mol})\end{array}$ & $\begin{array}{c}\text { Glucose } \\
\text { utilized } \\
(\mu \mathrm{mol})\end{array}$ & $\begin{array}{c}\text { Lactate } \\
\text { produced } \\
(\mu \mathrm{mol})\end{array}$ \\
\hline \multirow[t]{6}{*}{$2 \mathrm{~A}$} & None (control) & $8 \cdot 7$ & 0.030 & $1 \cdot 27$ & 2.45 \\
\hline & Oestradiol & $8 \cdot 2$ & 0.030 & $1 \cdot 24$ & $2 \cdot 48$ \\
\hline & Progesterone & $7 \cdot 7^{* *}$ & 0.030 & $1 \cdot 26$ & $2 \cdot 56^{*}$ \\
\hline & Lynoestrenol & $8 \cdot 2$ & 0.030 & $1 \cdot 23$ & $2 \cdot 39$ \\
\hline & Norethynodrel & $7 \cdot 6^{* *}$ & 0.030 & $1 \cdot 26$ & $2 \cdot 44$ \\
\hline & s.e.m. & $0 \cdot 3$ & 0.000 & 0.02 & 0.04 \\
\hline \multirow[t]{6}{*}{$2 B$} & None (control) & $8 \cdot 4$ & 0.039 & 1.45 & 2.93 \\
\hline & Oestradiol & $7 \cdot 3^{*}$ & 0.033 & 1.48 & $3 \cdot 36^{* * *}$ \\
\hline & Progesterone & $3 \cdot 1 * * *$ & $0.015^{* * *}$ & $1 \cdot 15^{* * *}$ & 3.05 \\
\hline & Lynoestrenol & $8 \cdot 5$ & 0.036 & $1 \cdot 47$ & $3 \cdot 17^{* *}$ \\
\hline & Norethynodrel & $4 \cdot 0^{* * *}$ & $0.018^{* * * *}$ & $0.92 * * *$ & $2 \cdot 46^{* * *}$ \\
\hline & s.e.m. & 0.49 & 0.003 & 0.05 & 0.07 \\
\hline
\end{tabular}

Values represent the means of 5 replicates and are calculated per $10^{8}$ spermatozoa per $3 \mathrm{~h}$.

Significantly different from control value, ${ }^{*} P<0.05,{ }^{* *} P<0.01,{ }^{* * *} P<0.001$.

\section{Energy metabolism in the presence and absence of steroids}

The spermatozoa were incubated under anaerobic conditions to determine whether the steroids were having a direct effect on the Embden-Meyerhof pathway. Progesterone and norethynodrel produced a slight inhibition of the rate of anaerobic glycolysis (Table 3, Exp. 3A). Oestradiol, however, resulted in a slight increase in the amount of lactate produced by the spermatozoa but had no significant effect on the amount of glucose utilized. Lynoestrenol had no significant effect on the anaerobic glycolytic metabolism of the spermatozoa.

Table 3. The effect of steroids $(320 \mathrm{nmol} / \mathrm{ml})$ on the metabolism of washed spermatozoa

\begin{tabular}{|c|c|c|c|c|c|c|c|c|c|}
\hline \multicolumn{3}{|c|}{ Experiment } & \multirow[b]{2}{*}{$\begin{array}{l}\text { Reaction } \\
\text { measured }\end{array}$} & \multicolumn{6}{|c|}{ Steroid } \\
\hline No. & Conditions & Substrate & & $\begin{array}{c}\text { None } \\
\text { (control) }\end{array}$ & $\begin{array}{l}\text { Oestra- } \\
\text { diol }\end{array}$ & $\begin{array}{l}\text { Proges- } \\
\text { terone }\end{array}$ & $\begin{array}{c}\text { Lyn- } \\
\text { oestrenol }\end{array}$ & $\begin{array}{l}\text { Norethy- } \\
\text { nodrel }\end{array}$ & s.e.m. \\
\hline \multirow[t]{2}{*}{$3 \mathrm{~A}$} & Anaerobic & Glucose & $\begin{array}{l}\text { Glucose utilized } \\
(\mu \mathrm{mol})\end{array}$ & 1.63 & 1.78 & $1 \cdot 30^{* *}$ & 1.51 & $1 \cdot 23^{* * *}$ & 0.09 \\
\hline & & & $\begin{array}{l}\text { Lactate produced } \\
\quad(\mu \mathrm{mol})\end{array}$ & $3 \cdot 05$ & $3 \cdot 38^{*}$ & $2 \cdot 57^{* *}$ & $2 \cdot 93$ & $2 \cdot 22^{* * * *}$ & 0.12 \\
\hline \multirow[t]{2}{*}{ 3B } & Aerobic & {$\left[1{ }^{14} \mathrm{C}\right]$ Acetate } & $\begin{array}{l}\text { Oxygen uptake } \\
(\mu l)\end{array}$ & $9 \cdot 7$ & 8.9 & $2 \cdot 6^{* * *}$ & $9 \cdot 1$ & $4 \cdot 4 * * *$ & 0.40 \\
\hline & & & $\begin{array}{l}\text { Acetate oxidized } \\
\quad(\mu \mathrm{mol})\end{array}$ & 0.057 & 0.052 & $0.035^{* * *}$ & 0.053 & $0 \cdot 036^{* * *}$ & 0.003 \\
\hline $3 C$ & Endogenous & None & Oxygen uptake & $10 \cdot 4$ & $10 \cdot 4$ & $2 \cdot 9 * * *$ & $8.9^{*}$ & $2 \cdot 9 * * *$ & 0.63 \\
\hline
\end{tabular}

Values represent the means of 3 (Exp. $3 \mathrm{~A}$ ) or 4 (Exps $3 \mathrm{~B}$ and $3 \mathrm{C}$ ) replicates and are calculated per $10^{8}$ spermatozoa per $3 \mathrm{~h}$.

Significantly different from control value, ${ }^{*} P<0.05,{ }^{* *} P<0.01,{ }^{* *} P<0.001$. 
The influence of the steroids on the tricarboxylic acid (TCA) cycle was examined in Exp. 3B in which acetate (which directly enters the TCA cycle after conversion to acetyl-CoA) was the substrate. Only progesterone and norethynodrel had any effect (Table 3 ). Progesterone and norethynodrel also significantly depressed the oxygen consumption of the spermatozoa when incubated without any exogenous energy source (Table 3, Exp. 3C); lynoestrenol produced a small inhibition.

\section{Effect of norethynodrel on the oxidation of labelled citric acid cycle intermediates}

As shown in Table 4, norethynodrel depressed the oxygen consumption of spermatozoa incubated in the presence of all three substrates and inhibited the oxidation of the intermediates. $\alpha$-Ketoglutarate was oxidized by the spermatozoa at a greater rate than either malate or succinate.

Table 4. The effect of norethynodrel $(320 \mathrm{nmol})$ on the oxidation of $\alpha-\left[5-{ }^{14} \mathrm{C}\right] \mathrm{ket}$ (oglutarate, $\left[1,4-{ }^{14} \mathrm{C}\right] \mathrm{succinate}$ and $\mathrm{L}-\left[\mathrm{U}-{ }^{14} \mathrm{C}\right] \mathrm{malate}$ by washed human spermatozoa

\begin{tabular}{|c|c|c|c|c|c|c|}
\hline & \multicolumn{3}{|c|}{ Oxygen uptake $(\mu 1)$ with: } & \multirow{2}{*}{$\begin{array}{l}\text { Ketoglutarate } \\
\text { oxidized } \\
(\mu \mathrm{mol})\end{array}$} & \multirow{2}{*}{$\begin{array}{c}\text { Succinate } \\
\text { oxidized } \\
(\mu \mathrm{mol})\end{array}$} & \multirow{2}{*}{$\begin{array}{c}\text { Malate } \\
\text { oxidized } \\
\text { ( } \mu \text { mol) }\end{array}$} \\
\hline & Ketoglutarate & Succinate & Malate & & & \\
\hline Control & $8 \cdot 9$ & $14 \cdot 2$ & $10 \cdot 7$ & 0.0357 & 0.0110 & 0.0096 \\
\hline Norethynodrel & $1 \cdot 5$ & $4 \cdot 9$ & $2 \cdot 3$ & 0.0175 & 0.0041 & 0.0033 \\
\hline
\end{tabular}

Summary of the analysis of variance

\begin{tabular}{lccc}
\hline \multirow{2}{*}{ Source of variation } & & \multicolumn{2}{c}{ Variance ratios } \\
\hline Effect of steroid (A) & d.f. & Oxygen uptake & Substrate oxidized \\
Between substrates (B) & 1 & $396 \cdot 82^{* *}$ & $33 \cdot 21^{* *}$ \\
Interaction A x B & 2 & $37 \cdot 90^{* *}$ & $52 \cdot 55^{* *}$ \\
Between replicates & 2 & $1 \cdot 44$ & $4 \cdot 95^{*}$ \\
Replicate interactions (error) & 3 & $7 \cdot 64^{* *}$ & $6 \cdot 28^{* *}$ \\
& 15 & 1.05 & 0.0000196 \\
\hline
\end{tabular}

Values represent the means of 3 replicates and are calculated per $10^{8}$ spermatozoa per $3 \mathrm{~h}$.

${ }^{*} P<0.05,{ }^{* *} P<0.01$.

Table 5. The effect of steroids on the motility (as \% of motile spermatozoa) of washed human spermatozoa incubated at $37^{\circ} \mathrm{C}$ in $1 \mathrm{ml} \mathrm{KRP} \mathrm{diluent} \mathrm{containing} 10 \mathrm{~mm}$-D-glucose

\begin{tabular}{|c|c|c|c|c|c|}
\hline \multirow[b]{2}{*}{ Exp. } & \multirow[b]{2}{*}{ Steroid } & \multicolumn{4}{|c|}{ Incubation time } \\
\hline & & $0 \mathrm{~min}$ & $30 \mathrm{~min}$ & $1 \mathrm{~h}$ & $4 h$ \\
\hline \multirow[t]{4}{*}{$5 A$} & None (control) & 54 & 54 & 54 & 45 \\
\hline & Oestradiol (320 nmol) & 54 & 54 & 54 & 41 \\
\hline & Progesterone $(320 \mathrm{nmol})$ & 54 & $50^{* *}$ & $45^{* * *}$ & $24^{* * *}$ \\
\hline & s.e.m. & 0 & $1 \cdot 0$ & $1 \cdot 7$ & 1.8 \\
\hline \multirow[t]{8}{*}{$5 B$} & None (control) & 55 & 55 & 55 & 50 \\
\hline & Lynoestrenol $(320 \mathrm{nmol})$ & 55 & $33^{* *}$ & $18^{* * *}$ & $8^{* * *}$ \\
\hline & Lynoestrenol $(32 \mathrm{nmol})$ & 55 & $13 * * *$ & $10^{* * *}$ & $0 * * *$ \\
\hline & Lynoestrenol $(3.2 \mathrm{nmol})$ & 55 & 50 & 53 & 35 \\
\hline & Norethynodrel $(320 \mathrm{nmol})$ & 55 & $2 * * *$ & $0^{* * *}$ & $0 * * *$ \\
\hline & Norethynodrel $(32 \mathrm{nmol})$ & 55 & 47 & 47 & $3 * * *$ \\
\hline & Norethynodrel $(3.2 \mathrm{nmol})$ & 55 & 55 & 53 & $32^{*}$ \\
\hline & s.e.m. & 0 & $6 \cdot 7$ & $4 \cdot 1$ & $7 \cdot 7$ \\
\hline
\end{tabular}

Values represent the means of 4 (Exp. 5A) or 3 (Exp. 5B) replicates.

Significantly different from control value, ${ }^{*} P<0.05,{ }^{* *} P<0.01,{ }^{* * *} P<0.001$. 


\section{Effect of steroids on the motility of spermatozoa}

As shown in Table 5, oestradiol had no detectable effect on the motility of the spermatozoa over the 4-h incubation, but the three progestagens had a strong inhibitory effect.

Table 6. Loss of cell components from human spermatozoa caused by the addition of steroids $(320 \mathrm{nmol})$

\begin{tabular}{|c|c|c|c|c|}
\hline Exp. & Steroid & $\begin{array}{l}\text { Oxygen uptake } \\
\qquad(\mu \mathrm{l})\end{array}$ & $\begin{array}{l}\text { Total absorbance of } \\
\text { supernatant fluid after } \\
\text { 6-fold dilution } \\
(\lambda=260 \mathrm{~nm})\end{array}$ & $\begin{array}{c}\text { Total protein in } \\
\text { supernatant fluid } \\
(\mu \mathrm{g} / \mathrm{ml})\end{array}$ \\
\hline \multirow[t]{4}{*}{$6 \mathrm{~A}$} & None (control) & $10 \cdot 4$ & 0.026 & 230 \\
\hline & Lynoestrenol & $7 \cdot 2^{* *}$ & 0.012 & $280^{* * *}$ \\
\hline & Norethynodrel & $3 \cdot 5 * * *$ & $0 \cdot 142 * * *$ & $276^{* * *}$ \\
\hline & s.e.m. & 0.69 & 0.0104 & $9 \cdot 0$ \\
\hline \multirow[t]{4}{*}{$6 \mathrm{~B}$} & None (control) & $11 \cdot 7$ & 0.042 & 265 \\
\hline & Oestradiol & $11 \cdot 0$ & $0.004 * * *$ & 299 \\
\hline & Progesterone & $2 \cdot 9^{* * *}$ & $0 \cdot 188^{* * *}$ & $302 *$ \\
\hline & s.e.m. & 0.43 & 0.0100 & $16 \cdot 2$ \\
\hline
\end{tabular}

Values represent the means of 3 replicates and are calculated per $10^{8}$ spermatozoa per $3 \mathrm{~h}$.

Significantly different from control value, ${ }^{*} P<0.05,{ }^{* *} P<0.01,{ }^{* * *} P<0.001$.

\section{Effect of steroids on the integrity of the sperm plasma membrane}

Cell components with an absorbance at $260 \mathrm{~nm}$ were lost into the supernatant fluid when steroids were added to the spermatozoa (Table 6). All 3 progestagens caused loss of soluble protein from the cell, but only norethynodrel and progesterone caused loss of components with absorbance at $260 \mathrm{~nm}$. The effects of the steroid treatments on the oxygen uptake of the spermatozoa were similar to those of Exp. 3C (Table 3).

\section{Discussion}

The large range of steroid doses used in the present investigation varied from concentrations of steroids reported in the female genital tract of women given steroid contraceptives systemically (Laumas et al., 1971) to those which may possibly be expected in the genital tract of women with a steroid releasing intrauterine or intravaginal device (Leone, 1974; Martínez-Manautou, 1975; World Health Organization, 1976). Rosado et al. (1974) have suggested the importance of a direct inhibition of sperm capacitation by the uterine secretions of women using progesterone-T devices. Since the maintenance of motility of spermatozoa appears to be important in several species for the passage of the spermatozoa through the egg investments (Yanagimachi, 1966, 1969, 1972), and since the processes of capacitation and the acrosome reaction of spermatozoa are possibly metabolically controlled (Rogers \& Yanagimachi, 1975; Rogers, Ueno \& Yanagimachi, 1977), the inhibition of sperm metabolism and motility by progesterone observed in the present investigation suggests that one contraceptive effect of the progesterone-T device could be the direct action of progesterone on the spermatozoa.

However, the results with the other progestagens in the present study suggest that they may influence human spermatozoa by two different mechanisms. Progesterone and norethynodrel inhibited both the motility and oxidative metabolism of the spermatozoa and produced a significant loss of $260 \mathrm{~nm}$-absorbing materials from the cells, suggesting that they may act on the sperm plasma membrane to increase its permeability, and hence facilitate the loss of essential cofactors required for glycolytic and oxidative processes. Further work is required to assess whether these steroids directly affect catabolic reactions of spermatozoa. 
Lynoestrenol, however, inhibited motility but did not produce any significant change in oxidative metabolism or cause excessive loss of $260 \mathrm{~nm}$-absorbing material from the spermatozoa. Its action may involve steroid binding sites on the plasma membrane (Hyne \& Boettcher, 1977), leading to a disruption of a membrane function associated with sperm motility. The direct action of lynoestrenol on spermatozoa allows its use as a biochemical probe to investigate a possible sperm-specific effect of progestagens on spermatozoa because flagellar motility is unique to the sperm cell in man.

Further investigations on the direct effect of steroids on spermatozoa may lead to the development of a sperm-specific steroid that would act directly on spermatozoa at low concentrations to affect sperm fertilizing capacity adversely. Such a compound could be released from a reservoir in an intravaginal or an intracervical device to prevent sperm migration.

This work was supported by a grant to B. Boettcher from the World Health Organization (project number 74250). We thank Mr Frank Peddie (Searle Laboratories) for the gift of norethynodrel and Dr I. R. Butt (Organon) for the gift of lynoestrenol.

\section{References}

Barker, J.N. \& Britton, H.G. (1957) The enzymatic estimation of $\mathrm{L}(+)$ lactic acid. J. Physiol., Lond. 138, $3 P-4 P$.

Beck, K.J., Herschel, S., Hungershöfer, R. \& SCHWINGER, E. (1976) The effect of steroid hormones on motility and selective migration of $\mathrm{X}$ - and $\mathrm{Y}$ bearing human spermatozoa. Fert. Steril. 27, 407412.

Boettcher, B. (1974) The molecular nature of spermagglutinins and sperm antibodies in human sera. $J$. Reprod. Fert., Suppl. 21, 151-167.

Boetrcher, B. \& KAY, D.J. (1973) Agglutination of spermatozoa by human sera with added steroids. Andrologie 5, 265-271.

Boettcher, B., Hay, J., Kay, D.J., Baldo, B.A. \& ROBERTS, T.K. (1970) Spermagglutinating activity in some human sera. Int. J. Fert. 15, 143-158.

Braunsberg, H., Irvine, W.T. \& James, V.H.T. (1967) A comparison of steroid hormone concentrations in human tissues including breast cancer. $B r$.J. Cancer 21, 714-729.

DeLuCA, H.F. (1972) Methods for preparation and study of tissues and enzymes. In Manometric and Biochemical Techniques, 5th edn, pp. 146-147. Eds W. W. Umbreit, R. H. Burris \& J. F. Stauffer. Burgess Publishing Company, Minneapolis.

Gallegos, A.J., González-Diddi, M., Merino, G. \& Martínez-Manautou, J. (1970) Tissue localization of radioactive chlormadinone acetate and progesterone in the human. Contraception 1, 151-161.

Hicks, J.J., Pedron, N. \& Rosado, A. (1972) Modifications of human spermatozoa glycolysis by cyclic adenosine monophosphate (cAMP), estrogens and follicular fluid. Fert. Steril. 23, 886-893.

HuggetT, A.Sr.G. \& Nixon, D.A. (1957) Enzymic determination of blood glucose. Biochem. J. 66, $12 P$.

HyNe, R.V. \& BoetTcher, B. (1977) The selective binding of steroids by human spermatozoa. Contraception 15, 163-174.

KESSERÜ-Koos, E. (1971) Influence of various hormonal contraceptives on sperm migration in vivo. Fert. Steril. 22, 584-603.

Kesserü, E., Camacho-Ortega, P., Laudahn, G. \& Schöpflin, G. (1975) In vitro action of progestagens on sperm migration in human cervical mucus. Fert. Steril. 26, 57-61.

Laumas, K.R., Murugesan, K. \& Hingorani, V. (1971) Disappearance in plasma and tissue uptake of radioactivity after an intravenous injection of $\left[6,7-{ }^{3} \mathrm{H}\right]$ norethynodrel in women. Acta endocr., Copenh. 66, 385-400.

LeONE, U. (1974) "Uterine progesterone system (U.P.S.)": a new form of intrauterine contraception. Int. J. Fert. 19, 17-18.

Lindahl, P.E., Ingelman-Sundberg, A., Furuhjelm, M. \& Nilsson, A. (1956) The sperm anti-agglutinic factor in women. J. Obstet. Gynaec. Br. Emp. 63 , 363-371.

Lowry, O.H., Rosebrough, N.J., FarR, A.L. \& RANDALL, R.J. (1951) Protein measurement with the folin phenol reagent. J. biol. Chem. 193, 265275.

Martínez-Manautou, J. (1975) Contraception by intrauterine release of progesterone-clinical results. J. Steroid Biochem. 6, 889-894.

Patterson, M.S. \& Greene, R.C. (1965) Measurement of low energy beta-emitters in aqueous solution by liquid scintillation counting of emulsions. Analyt. Chem. 37, 854-857.

Reed, M.J., Fotherby, K., Peck, J.E. \& Gordon, Y. (1973) Localization of norethisterone in the reproductive tract of women. $J$. Endocr. 59, 569577.

Reed M.J., Fotherby, K. \& Steele, S.J. (1973) Localization of ethynyloestradiol in the reproductive tract of women. J. Endocr. 58, 643-656.

Rogers, B.J. \& Yanagimachi, R. (1975) Retardation of guinea pig sperm acrosome reaction by glucose: the possible importance of pyruvate and lactate metabolism in capacitation and the acrosome reaction. Biol. Reprod. 13, 568-575.

Rogers, B.J., Ueno, M. \& YanagimaChi, R. (1977) Inhibition of hamster sperm acrosome reaction and fertilization by oligomycin, antimycin $A$ and rotenone. J. exp. Zool. 199, 129-135.

Rosado, A., Hicks, J.J., Aznar, R. \& Mercado, E. (1974) Intrauterine contraception with the progesterone-T device. Contraception 9, 39-51. 
World Health Organization (1976) Expanded programme of research, development and research training in human reproduction. Sth Annual Report, pp. 32-41.

YanagimaChI, R. (1966) Time and process of sperm penetration into hamster ova in vivo and in vitro. $J$. Reprod. Fert. 11, 359-370.
YANAGIMACHI, R. (1969) In vitro capacitation of hamster spermatozoa by follicular fluid. J. Reprod. Fert. 18, 275-286.

YANAGIMACHI, R. (1972) Fertilization of guinea pig eggs in vitro. Anat. Rec. 174, 9-20.

Received 27 October 1977 